Hiroshi Umemura, Peter Zieme

\title{
A Further Fragment of the Old Uighur Qianziwen
}

In memoriam Masahiro Shōgaito

Abstract: In this paper the authors edit one fragment of the Old Uighur Qianziwen that belongs to the Serindia Collection of the Institute of Oriental Manuscripts of the Russian Academy of Sciences at St. Petersburg. This fragment is joined with some others that were already published by M. Shōgaito. The Qianziwen belonging to the classical scriptures is an old Chinese primer for learning Chinese. Rarely translated into other languages the Old Uighur version confirms the strong relationship between Chinese and Uighur scholarship in the Medieval period.

Key words: Qianziwen, Thousand Characters Book, Chinese primer, Old Uighur fragments, Serindia Collection, translations from Chinese into Old Uighur

Beyond doubt one of the great achievements of late Masahiro Shōgaito is his work on Old Uighur texts and their dependence on and relationship to the Chinese originals. The texts he studied and edited include the 千字文 Qianziwen an old Chinese primer used for learning Chinese. In the Middle Ages this Chinese text was rarely translated into other languages. Among the Old Uighur materials quite a few fragments were identified, mainly by Shōgaito, one contribution was written by him together with Abdurishid Yakup (SHŌGAITO and YAKUP 2001).

At that time the authors referred to three Old Uighur translations. The first they mention is $\mathrm{Ch} / \mathrm{U} 8152 \mathrm{v}$ studied by Tsuneki Nishiwaki, ${ }^{1}$ but this is not a

(C) Hiroshi Umemura, Chuo University, Tokyo

(c) Peter Zieme, Free University, Berlin

${ }^{1} \mathrm{Cp}$. NishiwaKi 2002, 70-87. $\mathrm{Ch} / \mathrm{U} 8152$ verso contains the Old Uighur phrase [min užjiklarnıı čızıgl translated by SHŌGAITO and YAKUP 2001, 4 as "The Essay of a Thousand Characters" with the unconventional use of člzıg "line" (not included in ED); cp. strophe 21 of the Old Uighur Qianziwen: 始制文字 shi zhi wen $z i=\check{s} u$ či 文字 = ašnu-ča yaratıp užik $\check{c} \iota z ı g=$ "First they created syllables and lines". 
"block print" as the authors write. ${ }^{2}$ The second manuscript is known from SI $4000(4 \mathrm{bKr} 182){ }^{3}$ SI $4006(4 \mathrm{bKr} 194)^{4}$ and SI $\left.4084(4 \mathrm{bKr} 185)\right)^{5}$ The third manuscript is SI 4083 (4bKr 181). ${ }^{6}$ They did not mention a fourth. ${ }^{7}$

In 2003, Shōgaito discussed some more fragments that he had already edited before: SI $5778(3 \mathrm{Kr} 14)$ and SI $5836(3 \mathrm{Kr} 15)^{8}$ without specifying to which manuscript they belong. They apparently constitute a fifth manuscript. In 2004 and 2008 he added SI 1787 (Kr IV 260) which also belongs to that same manuscript. ${ }^{9}$ All in all, there are five different manuscripts of Old Uighur versions of the Qianziwen.

Now, we are introducing here fragment SI 1850 ( $\mathrm{Kr}$ IV 312), which is a further part of the above-mentioned fifth manuscript. ${ }^{10}$ It can be joined directly to the other fragments and extends from line 37 to line 52, counting from the beginning. Altogether, the fifth manuscript covers the first 38 fourcharacter units of the Qianziwen, i.e., 152 characters. The four-character group is the structural unit of the Qianziwen and the Old Uighur translators followed this model.

Considering all the Qianziwen fragments known in Old Uighur, there are remnants of sections $1-38,82-101,104-117,114-146$ and 224-241. Altogether, this covers about 440 characters, thus so far nearly half of the Qianziwen is attested in Old Uighur translation albeit in different manuscripts.

Taking into account that on the Chinese recto side one line has only 17 characters ${ }^{11}$ and considering the joint Uighur (verso) side, we can now better reconstruct the Old Uighur translation of the fifth manuscript. As a complete re-examination of the Qianziwen will be a future task, we start here from section 27 by including the new text of fragment SI 1850 (Kr IV 312).

\footnotetext{
${ }^{2}$ Shōgaito and YaKuP 2001, 4. In his other papers on the Qianziwen fragments Shōgaito does not call the text a "block print".

${ }^{3}$ Can be joined directly to SI 3924 (4bKr 155), not edited so far. We thank Akihito Yoshida for this information.

${ }^{4}$ Can be joined directly to SI 3864 (4bKr 38), not edited so far. We thank Akihito Yoshida for this information.

${ }^{5}$ ShōGaito and Yakup 2001, 4, studied as A, B, D.

${ }^{6}$ SHŌGaito and YAKUP 2001, 4, studied as C.

${ }^{7}$ ZIEME 1999; in SHŌGAITO 2003 it was mentioned.

${ }^{8}$ SHŌGAito 2008, 177.

${ }^{9}$ Shōgaito 2004, 184-201; Shōgaito 2008.

${ }^{10}$ We acknowledge our gratitude to I. F. Popova, the director of the Institute of Oriental Manuscripts of the Russian Academy of Sciences, St. Petersburg, for her support.

${ }^{11}$ The reconstruction in SHŌGAITO 2003, 117 presents a different picture.
} 


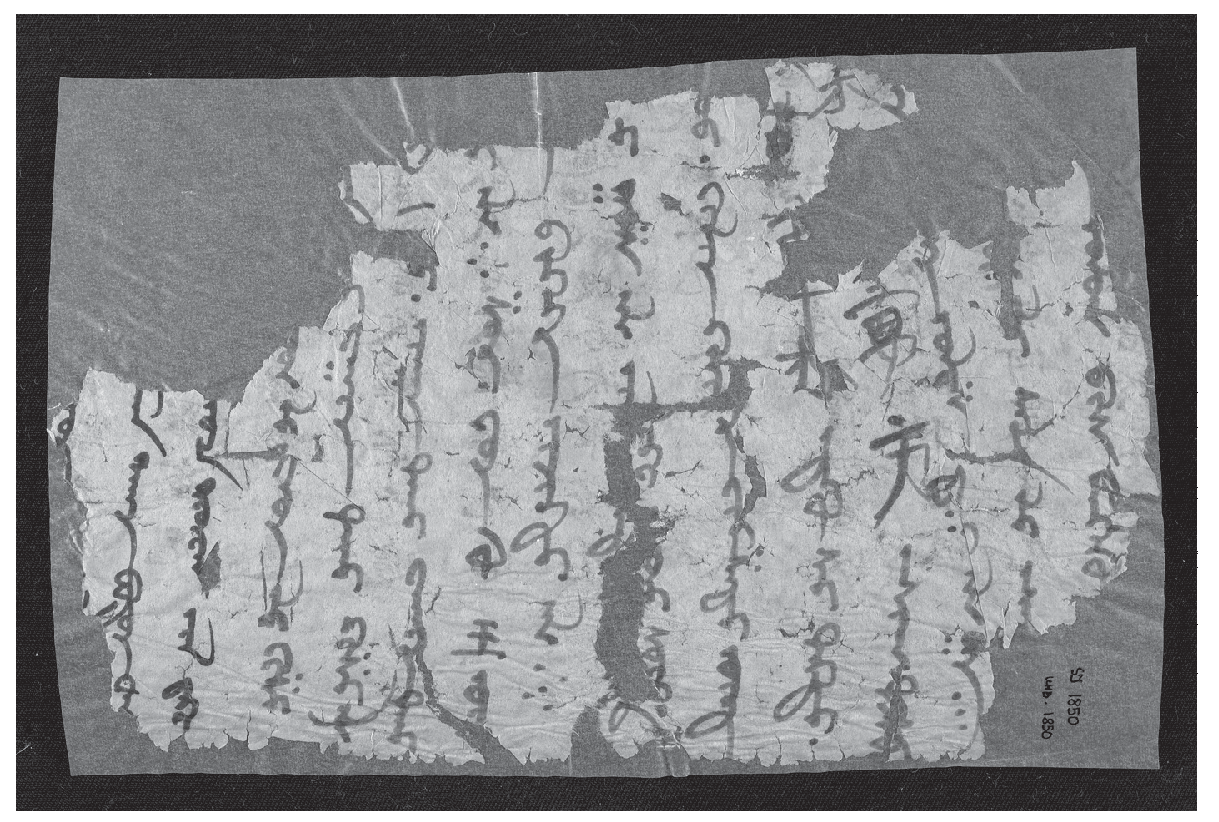

Qianziwen sections 27 to 38 according to the following structure

1) Section number;

2) Chinese characters and transcription in Pinyin;

3) English translation of Chinese, following the interpretation of the Chinese by Ōgawa and Kida; ${ }^{12}$

4) Chinese characters in the Old Uighur manuscript (characters only/transcription only/mixed) $;^{13}$

5) Transliteration of the Old Uighur text;

6) Transcription of the Old Uighur text (in Italic);

7) English translation of the Old Uighur text;

8) Commentary. ${ }^{14}$

\footnotetext{
${ }^{12}$ ŌGAWA and KIDA 1997, 56-69.

${ }^{13}$ Throughout the text there is no fixed arrangement. We guess that the translator chose the method of transcription in the case of difficult characters, but, of course, there is no proof of that.

${ }^{14}$ Our comments on the Chinese text are restricted to certain general information, but we try to give some detailed explanations to the Old Uighur version. Additionally we thought it appropriate to quote the nearest other non-Chinese version which is the Mongol text edited by HAUER 1925. For each section we give his text (without altering his transcription) and his translation into German.
} 


\section{7}

坐朝問道 zuo chao wen dao

Presiding at court and asking the way;

$(35)^{15} \mathrm{~s}^{\prime}$ čyv 問道 $^{16}$

kwyswnč lwk . (36) 'wrwn 'wyz" wlwrwp \{twylw $\}^{17}$ twyrw ywl yn "yydty

közünč-lüg (36) orun üzä olurup törü yol-ln ayıdtı

Sitting on the precious throne he asked the way of the law.

Comm.: The scribe quotes the text half in transcription, half as characters. Old Uig. közünčlüg orun "precious throne" is the equivalent of chao "court, palace". The "way" can have several meanings, here the Old Uighur translator interpreted it as "the way of the law". Cp. HAUER 1925, 5 (Mo.) baraglal-dur saguju yoso-yi asaguhui-dur (p. 12) "Sitzend zu Hofe erfragten sie das Tao." 18

\section{8}

垂拱平章 chui gong ping zhang

Not moving the hand, he fairly rules.

šw kwnk . (37) py čw

twn yn k'typ 'ylykyn yyrdynčwk p' šl'ty

tonin kädip eligin yertinčüg bašlatı

Putting on his dress by hand he ruled the world.

Comm.: The quotation is given only in transcription. There is no rule for quoting Chinese text, laying down which words were quoted as in the original Chinese text and which were transcribed. The first two characters 垂拱 chui gong mean "Wearing cloth and not moving the hand". One might assume that the translator left out a word for "not moving", but the converb speaks against this. He interpreted the binom simply as "putting on cloth". On the other hand, he added "by hand(s)" to the second binom. The translation of this binom makes it very clear that bašla- means "to rule", not only "to begin". We quote here a clear example from a passage in the Old Uighur translation of the Suvarnaprabhāsottamasūtra: (T. 665, p. 443c17) 以善化衆生,

\footnotetext{
${ }^{15}$ The numbers in round brackets ( ) correspond to the lines in the complete joined text of SI 5778 (3 Kr 14), SI 5836 (3 Kr 15), SI 1787 (Kr IV 260) and SI 1850 (Kr IV 312) following Shōgaito's publication.

${ }^{16}$ This character, which should be 道, is miswritten as 通 tong.

${ }^{17}$ The mistake $t w y l w$ was corrected by the scribe.

${ }^{18} \mathrm{Cp}$. HAUER 1925, 25.
} 
正法治於國 = Suv 565/3-6 (以善>) ädgügärü inčip (化>) ötläyür (衆生>) kamag kara bodunin / (正法>) köni nomča (治>) bašlayur (於國>) elniך ulušnuך törüsin "(The true ruler) advises his whole people to the good, he rules the law of the realm according to the true dharma" ${ }^{19}$ Here the verb 治 zhi "to govern" is translated by bašla- "id.". Cp. HAUER 1925, 5 nurkiju julgugulun tübsin bolgaju todorhailamui "(das Gewand) herabwallen lassend und die Hände vor der Brust gefaltet (d.h. in der Regungslosigkeit des Wuwei verharrend) klärten sie ausgleichend auf'. ${ }^{20}$

\section{9}

愛育黎首 ai yu li shou

With love he reared the common people.

(38) "y ywq 黎21首.

'mr'nm'q[ ]n 'ykytdy q'm'q q'r' pwdwn wq

amranmak[l]n egitdi kamag kara bodunug

In love he reared the whole people.

Comm.: The first half of the quotation is given in transcription, the other as characters. Here the translation is rather precise, with the exception that the translator added kamag "whole". The Chinese compound 黎首 lishou means "the common people". Cp. HAUER 1925, 5 hara terigütü irgen-i ürüsigen kümüjigüljü (p. 12) "Liebreich versorgten sie die schwarzen Häupter."

\section{0}

臣伏戎㒸 chen fu rong qiang

He administers that Rong and Qiang bend down.

$(39)^{22}$ šyn vwq šy kw ::

t'pyqčy qylyp y'v'ldwrty 'wč qytyq 'yl d'ky (40) kwyč'k mwnkwr wq l'r yq ::

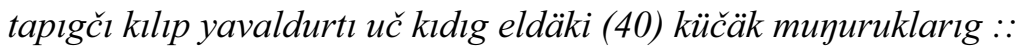

He made to servants and pacified the wild Bellowing Ones in the border lands.

Comm.: Here the translator quotes the Chinese text only in transcription. The names Rong and Qiang are used to exemplify the various western bar-

\footnotetext{
${ }^{19}$ KAYA 1994, 304.

${ }^{20}$ Cp. Hauer 1925, 25-26.

${ }^{21}$ This character, which should be 黎, is miswritten as 梨 $l i$.

${ }^{22}$ The first word in this line was erased; the scribe realised that it was miswritten.
} 
barian tribes. These are here replaced by a more general term: people living in the border regions. The word muyur-uk is not attested elsewhere, unless

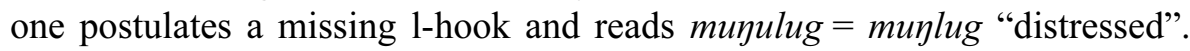
But, more probably, it seems to be a passive of the back vowel variant of the verb muңra-/münrä- "to bellow, howl, bleat". ${ }^{23}$ There are two possible routes

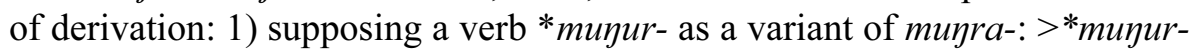

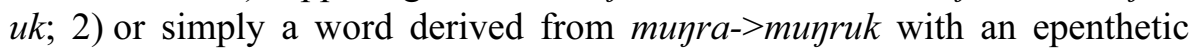
vowel > muyuruk. Cp. HAUER 1925, 5 gadagadu aimak tüsimel bolju dagara irejüküi "und machten untertan die Jung und die K' iang".

\section{1}

\section{遐雨壹體 xia er yi ti}

Far and near appear as one.

(([XXXX] özli yat-lı kiši-(41) -lär elig bägkä... [1]rak-takı yakın-takı kišilär (42) bir tözlüg boltı :: ) $)^{24}$

$q^{\prime}$ šy $-[t] y$

'yr'q t'qy y'qyn t'qy (43) [ ] ]šy l'r pyr twyzlwk pwlty l'r ::

ırak-takl yakın-takı (43) [ki]ši-lär bir tözlüg boltt-lar ::

People of far and near became like one.

Comm.: When the scribe realised that he had omitted to translate section 31 , he stopped and started to write the passage of that section, so he encircled the wrong passage with $((\ldots))$. Here, only the third character is quoted as Chinese character: - instead of 壹 "one". The word kišilär "people" is obviously an addition. The expression bir tözlüg corresponds to Chinese "of one body" = "the same". Cp. HAUER 1925, 5 holaki oiraki-yi anu nigen adali ïjijü "Die Fernen und die Nahen in corpore".

\section{2}

率賓歸王 shuai bin gui wang

All rallied, obeyed the king.

šwk vwn kw 王

'wyz (44) ly y'd ly kyšy l'r . 'ylyk p'kk' 'yčykdy l'r ::

öz (44) li yad-lı kiši-lär . elig bägkä ičikdi-lär :.

The own and the foreign people obeyed the king.

\footnotetext{
${ }^{23}$ ED $770 b$.

${ }^{24}$ The part $((\ldots))$ was erased.
} 
Comm.: Only the last character of the group is quoted as a Chinese character. "All", the first word of the Chinese line (shuai), was split into "the own and the foreign people" which might be caused by the second word bin "guest" or "to submit". In this case it is easier to understand the choice for yad "foreign", because a guest can also be foreign, of course. If the translator first thought of yad, he may have opted for $\ddot{z} z$, because the word pair $\ddot{z} z$ yad is frequent. Cp. HAUER 1925, 5 jergeber hagan-dur dagara iremüi (p. 12) "kehrten sich, führend und geführt, dem Weltherrscher zu".

\section{3}

鳴鳳在樹 ming feng zai shu

Calling phoenix is on the tree.

(45) 鳴 ${ }^{25}$ vwnk 在 šw :

ywy-y qwš l'r 'ylyky 'dty swykwd (46) 'wyz' :

yuy kuš-lar eligi ätti sögüt (46) üzä :

The king of the peacock birds sang on the tree.

Comm.: Two characters are quoted as Chinese, two in Old Uighur transcription. "The king of the peacocks" is a circumlocution for 鳳 feng "phoenix". In the Old Uighur translation of the Biography of Xuanzang feng is translated in the same manner. ${ }^{26}$ We think that although a special word denoting the peacock exists, 孔雀 kongque, in Old Uighur, yuy kuš could mean both peacock and phoenix. There are several examples for yuy kuš in the meaning of "peacock" ${ }^{27}$ Note the word ät- for "to sing" instead of $\ddot{o t}-$. Cp. HAUER 1925, 6 garudi hulusun modun dur dongotbai (p. 12) "Der singende Phönix war auf dem Baume".

\section{4}

白駒食場 bai ju shi chang

White pony grazes on threshing-floor.

白駒 ${ }^{28}$ 食 čW.

kylyn k' yyk yymš' dy 'wyrd- (47)-kwn t'kr' ::

kilin käyik yimšädi ürt- (47)-gün tägrä ::

The kilin animal grazed around the threshing-floor.

\footnotetext{
${ }^{25}$ This character remains unclear; most probably the scribe simply wrote another ming, i.e. 名.

${ }^{26}$ AYDEMIR 2013, 332-333 (com. on 1. 676).

${ }^{27}$ Cp. RYBATZKi 2008.

${ }^{28}$ Probably the scribe simply wrote a character similar in pronunciation: 記 $j i$ instead of 駒 $j u$.
} 
Comm.: The reading ürtgün, translation of Skt. khala "threshing place", is attested in Brāhmī script. ${ }^{29}$ The Old Uighur word kylyn kilin, spelled in TT I k'l'n kälän, is rare, it is not attested in ED as a lemma, ${ }^{30}$ but in TT I, $42^{31}$

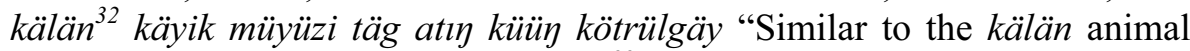
your name and fame will be exalted!" ${ }^{33}$ In their note to line 42 the editors explained kälän as a loan from the Chinese 麒麟 qilin, usually translated as "unicorn". This shows that the Uighur translator replaced "white pony" with the probably more familiar unicorn. Cp. the legend of Oguz Kagan where a difficult word $q-r-y-a-n$ is attested several times, a dog-like predatory animal, explained by some scholars as the unicorn. ${ }^{34}$ The Mongol version follows the Chinese text strictly, cp. HAUER 1925, 6 cagan daga küriyeleng dür idere iremüi (p. 12) "das weiße Fohlen fraß von der Tenne".

\section{5}

化被草木 hua bei cao mu

Wise teachings reach each plant and tree;

化被 ${ }^{36}$ 草木

tyn (?)' dkw sy t'kdy : (48) 'wt q' 'yq' č q't'ky ::

tin(?) ädgü-si tägdi : (48) ot-ka tgač-katägi ::

The virtue of heaven(?) reached to grass and trees.

Comm.: The Chinese group is quoted in full. The spelling of the first word is doubtful. Presumably, it is tyn $<$ Chin. 天 tian "heaven". If so, this seems to be an interpretation by the Old Uighur translator. Cp. HAUER 1925, 6 ebesü modun ece abun geskegdebei (p. 12) "der segensreiche Einfluß erstreckt sich bis auf die Pflanzen und die Bäume".

\footnotetext{
${ }^{29}$ MAUe 2015, 256 Nr. 51.

${ }^{30}$ But cp. ED 755a (sub kéyik) quoting the text of TT I, 42 as kilen keyik müyüzi teg. The editors of TT I used the spelling kälän or kilän in their note on p. 257.

${ }^{31} \mathrm{Cp}$. DTS 296a. The authors of the DTS adopted the etymology of TT I.

32
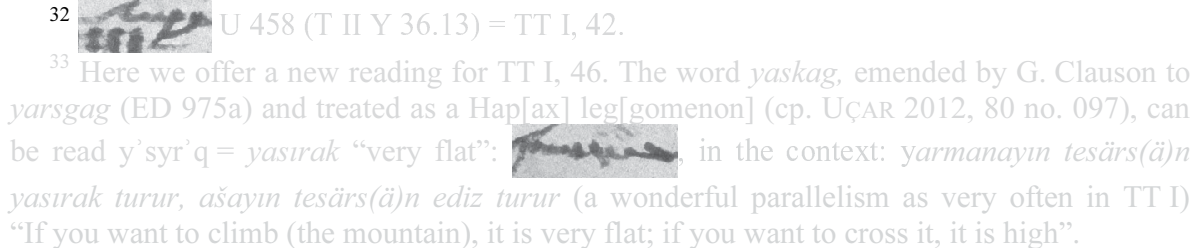

${ }^{34}$ Cp. Sinor 1960, 170-171.

皎盿白駒、食我場苗 “Let the brilliant white colt / Feed on the young growth of my vegetable garden" 
36

賴及萬方 lai ji wan fang

bounties reach everywhere.

賴 ${ }^{37}$ [及]萬方

'syq twsw (49) qylm'q yn yytkwrdy twy[ ]'n 'wlwš d' qy l'r q' ::

ası tusu (49) kllmak-ın yetgürdi tü [m]än uluš-dakl-lar-ka ::

By providing gain and profit he fostered those in ten thousand countries.

Comm.: In this line, too, all the Chinese characters are quoted. The Old Uighur translation tries to make the idea of the short Chinese phrase more plausible through circumlocution 万方 wanfang as uluš-dakl-lar-ka "those in ten thousand countries". The verb yetgür - "to make something available to somebody, help him reach it" is discussed by M. Erdal. ${ }^{38}$ Differently in Mongol, cp. HAUER 1925, 6 tümen gajara ki kesik yi küliyebei (p. 12) "und der Nutzen erreichte sämtliche Gegenden". 39

37

蓋此身髪 gai ci shen fa

Now, these bodies and hair

(50) q'y sy 身髪 40

ym' $[\ldots] z$ ly s'č ly 's[...] (51) [...]

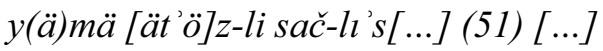

And the [bodie]s and the hair [...]

Comm.: It is a word by word translation, but we cannot emend the word 's[...]. Cp. HAUER 1925, 6 ene beye üsün kemekei (p. 12) "Nun sind diese Person und Haupthaare". ${ }^{41}$

\footnotetext{
${ }^{37}$ This character is difficult to recognise, only the left half can be seen and the right half was probably omitted.

${ }^{38}$ OTWF 755.

${ }^{39} \mathrm{Cp}$. Hauer's commentary.

${ }^{40}$ Instead of 髪 the scribe apparently used 八 $b a$ without any reason, unless one takes account of the similar pronunciation: $f a$ versus $b a$.

${ }^{41}$ According to Hauer's commentary (p. 28) this is an allusion to the Xiaojing I: 身體髮膚, 受之父母, 不敢毀傷, 孝之始也 “The body, hair and skin, all have been received from the parents, and so one doesn't dare damage them — that is the beginning of xiao."
} 


\title{
38
}

四大五常 si da wu chang

(are made from the) Four Great Things and (keep to the) Five Principles.

四大五常

[...]t 'wlwq pyš m'nkkw [...] (52) -' pwydmyš [...]

[tör]t ulug beš mängü [üz] (52) - ä bütmiš [ärür]

[By fou]r great (ones and) five eternal (principles) [they are] completed.

Comm.: The Four great (ones) are the constituents of the human body according to Buddhist theories: earth, wind, fire, and water, while the five eternal (principles) are the Confucian virtues: benevolence, righteousness, politeness, wisdom, and truthfulness. Cp. HAUER 1925, 6 dürben yeke tabun egüride (p. 12) "die Vier Großen und die Fünf Ewigen". ${ }^{42}$

\author{
Abbreviations \\ DTS - Drevenetiurkskii slovar \\ ED - Etymological Dictionary of Pre-Thirteenth-Century Turkish \\ OTWF - Old Turkic Word Formation \\ TT I — Türkische Turfan-Texte. I
}

\section{References}

AYDEMIR, Hakan 2013: Die alttürkische Xuanzang-Biographie IX. Nach der Handschrift von Paris, Peking und St. Petersburg sowie nach dem Transkript von Annemarie v. Gabain. III, Wiesbaden: Harrassowitz (Xuanzangs Leben und Werk, 10).

Drevnetiurkskii slovar' (DTS) 1968: Drevnetiurkskii slovar [Old Turkic dictionary]. Leningrad: Nauka.

Etymological Dictionary of Pre-Thirteenth-Century Turkish (ED) 1972: Clauson, Gerard. An Etymological Dictionary of Pre-Thirteenth-Century Turkish. Oxford: Oxford University Press.

HAUER, Erich 1925: "Das 千字文 Ts 'ien ${ }^{1}-$ tzĕ$^{4}$-wên ${ }^{2}$ in vier chinesischen Schriftformen mit einer mongolischen Übersetzung”. Mitteilungen des für Orientalische Sprachen XXVIII. Berlin: 1-47.

KAYA, Ceval 1994: Uygurca Altun Yaruk Sudur. Giriș, Metin ve Dizin, Ankara: Atatürk Kültür, Dil Ve Tarih Yüksek Kurumu. Türk Dil Kurumu Yayınları: 607.

MaUE, Dieter 2015: Alttürkische Handschriften. Teil 19: Dokumente in Brāhmī und tibetischer Schrift. Teil 2, Stuttgart: Franz Steiner Verlag (VOHD 13.27).

NISHIWAKI Tsuneki 西脇常記 2002: ドイツ将来のトルファン漢語文書 [Chinese documents in the Berlin Turfan Collection], Kyoto: Kyoto Daigaku Gakujutsu Shuppan-kai.

ŌGAWA Tamaki 小川環樹 and KIDA Akiyoshi 木田章義, 1997: 千字文 [Commentary to the Senjimon], Tokyo: Iwanami-shoten. Iwanami Bunko Ao 220-1.

\footnotetext{
${ }^{42}$ Cp. HaUer 1925, 28-29.
} 
Old Turkic Word Formation (OTWF) 1991: ERDAL, Marcel. Old Turkic Word Formation. A Functional Approach to the Lexicon. I-II, Wiesbaden: Harrassowitz.

RYBATZKI, Volker 2008: "Farbigkeit und Vielfalt: Einiges zum Pfau und seinen Bezeichnungen in den zentralasiatischen Sprachen”. 内陸アジア言語の研究 Studies on the Asian Languages 23, 187-207.

ShōGAITo Masahiro 2000: "Studies on the Uighur Fragments preserved in Russia. 2. Āgama, Qianziwen and Abhidarmakośa-bhāṣya-țīka-Tattvārthā”. Kyoto University Linguistic Research 19, 147-191+6.

SHŌGAITo Masahiro 2001: "Studies on the Uighur Fragments preserved in Russia 3". Kyoto University Linguistic Research 20, 243-277+5.

SHōGAITo Masahiro 2003: Uighur Manuscripts in St. Petersburg - Chinese Texts in Uighur Script and Buddhist Texts. Kyoto: Graduate School of Letters Kyoto University.

SHōGAITo Masahiro 2004: "Studies on Uighur fragments preserved in Russia". Kyoto University Linguistic Research 23, 191-209.

SHŌGAITO Masahiro 2008: "Uigurskii fragment pod shifrom SI Kr.IV 260 iz sobraniia Instituta vostochnykh rukopisei RAN" [Uighur fragment SI Kr.IV 260 from collections of Institute of Oriental Manuscripts RAS]. Pis 'mennye pamiatniki Vostoka (1)8, 177-186.

SHŌGAITO Masahiro and YAKUP Abdurishid 2001: "Four Uyghur fragments of Qian-zi-wen "Thousand Character Essay"'. Turkic languages 5, 3-28.

SINOR, Denis 1960: "Sur les noms altaïques de la licorne". Wiener Zeitschrift für die Kunde des Morgenlandes 56, 168-176.

Türkische Turfan-Texte. I (TT I) 1929: BANG, Willi and GABAIN, Annemarie von. Türkische Turfan-Texte. I. Bruchstücke eines Wahrsagebuches, Sitzungsberichte der Preussischen Akademie der Wissenschaften, 241-268.

UÇAR, Erdem 2012: "Eski Türkçe Hapakslar". Modern Türklük Araştırmaları Dergisi, 9.1 (Mart), 73-100.

ZIEME, Peter 1999: "Das Qiānzìwén bei den alten Uighuren". Writing in the Altaic World. Ed. by J. Janhunen and V. Rybatzki, Helsinki: 321-326 (Studia Orientalia 87). 